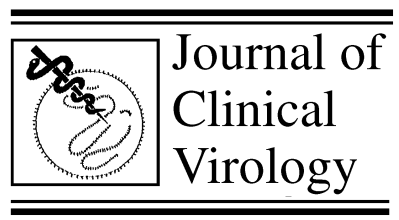

Www.elsevier.com/locate/jcv

\title{
Retrovirus infections in a sample of injecting drug users in Rio de Janeiro City, Brazil: prevalence of HIV-1 subtypes, and co-infection with HTLV-I/II
}

\author{
Monick Lindenmeyer Guimarães ${ }^{\mathrm{a}}$, Francisco Inácio Bastos ${ }^{\mathrm{b}}$, \\ Paulo R. Telles ${ }^{c}$, Bernardo Galvão-Castro ${ }^{\mathrm{d}}$, Ricardo S. Diaz ${ }^{\mathrm{e}}$, \\ Vera Bongertz ${ }^{a}$, Mariza Gonçalves Morgado ${ }^{\text {a,* }}$ \\ ${ }^{a}$ Laboratory of AIDS and Molecular Immunology, Department of Immunology, Oswaldo Cruz Institute, \\ FIOCRUZ (UNAIDS Collaborative Centre), Av. Brasil, 4365 Manguinhos, 21045-900 Rio de Janeiro, Brazil \\ ${ }^{\mathrm{b}}$ Department of Health Information, Center for Information on Science and Technology, \\ FIOCRUZ (UNAIDS Collaborative Centre), Rio de Janeiro, Brazil \\ ${ }^{\mathrm{c}}$ Center for Drug Abuse Treatment and Research (NEPAD), State University of Rio de Janeiro, Rio de Janeiro, Brazil \\ d Advanced Public Health Laboratory, Gonçalo Moniz Research Center, FIOCRUZ (UNAIDS Collaborative Centre), Bahia, Brazil \\ e Laboratory of Retrovirology, Federal University of São Paulo, São Paulo, Brazil
}

Received 10 July 2000; received in revised form 15 December 2000; accepted 5 February 2001

\begin{abstract}
Background: Retrovirus infections among injecting drug users (IDUs), a core at-risk population for both HIV-1 and HTLV-I/II infections in Brazil, were assessed within an ongoing cooperative research. Objective: The study assessed the seroprevalences of HIV-1 and HTLV-I/II infections, as well as the prevalence of HIV-1 subtypes in a sample of IDUs from Rio de Janeiro, Brazil. An attempt to evaluate HIV incidence was carried out using a dual 'sensitive/less sensitive' testing strategy. Study design: Cross-sectional evaluation of 175 IDUs. Serostatus for HIV-1 and HTLV-I/II were established by enzyme-linked immunosorbent assays, and confirmed by western blot. The dual testing strategy aimed to estimate HIV-1 incidence rates. Differentiation between HTLV-I and -II was performed by western blot. DNA samples were polymerase chain reaction amplified by a nested protocol, and HIV-1 subtyping was determined by heteroduplex mobility assay. Results: Forty-six and 29 samples were found to be, respectively, positive for HIV-1 and HTLV-I/II, 15 of them co-infected by both viruses. Among HTLV-I/II-infected patients, 75.9\% were infected by HTLV-I. Thirty-one HIV samples were identified as B subtype, with seven of them showing the typical 'Brazilian B' pattern in the gp120 V3 loop, and ten were identified as F subtype. The use of less sensitive assays for HIV infection wrongly identified a deeply immunocompromised patient as an incident case. Conclusion: Moderately high seroprevalences were found for both HIV-1 and HTLV-I/II infections, HIV-1/HTLV-I co-infections being of special concern. A non-statistically significant higher prevalence of $\mathrm{F}$ subtype was observed, when compared with the distribution of F/B subtypes among Brazilian patients from other exposure categories. No recent HIV-1 infections were detected, but
\end{abstract}

\footnotetext{
* Corresponding author.

E-mail address: morgado@gene.dbbm.fiocruz.br (M.G. Morgado).
} 
a limitation of the 'sensitive/less-sensitive' testing strategy was made evident. (C) 2001 Elsevier Science B.V. All rights reserved.

Keywords: Injecting drug users; HIV; HTLV; HIV/HTLV co-infection; Sensitive/less sensitive dual testing strategy for HIV infection

\section{Introduction}

As of June 2000, 190949 cases (AIDS Epidemiological Bulletin, 2000) of AIDS have been reported in Brazil, with approximately $19 \%$ of them reported among injecting drug users (IDUs). IDUs are the second most common form of exposure for HIV-1 infection and AIDS in Brazil, after cases acquired through heterosexual transmission, which accounts for $24 \%$ of the AIDS cases registered to date (AIDS Epidemiological Bulletin, 2000). The role of IDUs in the dynamics of the AIDS epidemic has changed dramatically since the middle of the 1980s. Between 1982 and 1986, IDUs represented only $3 \%$ of Brazilian AIDS cases. Since 1991, they have represented about $20 \%$ or more of the total number of cases. Cocaine is the main illicit drug injected in Brazil, and the reported AIDS cases among IDUs are concentrated along the main cocaine-trafficking routes (Bastos et al., 1999). The increasing number of AIDS cases in this exposure category has resulted in a further increase of the number of AIDS cases reported among IDUs' sexual partners and of the vertical transmission of HIV. In Brazil, around $23 \%$ of the women diagnosed with AIDS in the past 5 years were IDUs and, among heterosexuals, $33 \%$ were sexual partners of male IDUs (Telles et al., 1997).

Several studies about HIV diversity in Brazil have shown the presence of at least four HIV-1 subtypes so far: B, F, C, and D (Potts et al., 1993; Couto-Fernandez et al., 1994; Lowagie et al., 1994; Morgado et al., 1994, 1998a; WHO National Network for HIV Isolation and Characterization, 1994b; Janini et al., 1996), as well as B/F and B/C recombinant viruses (Sabino et al., 1994; Cornelissen et al., 1996; Gao et al., 1996). Data from the state of São Paulo, where roughly $75 \%$ of the AIDS cases among IDUs were registered (Bastos et al., 1999), suggested an association between HIV-1 subtype F and IDUs (Sabino et al., 1996; Rossini et al., 2001). However, Brazil is a large country, and local differences on HIV/ AIDS subepidemics and HIV-1 subtype distribution have been observed (Morgado et al., 1998a). The city of Rio de Janeiro has the second highest prevalence of AIDS cases in the country, with 28219 cases reported until June 2000; approximately $6 \%$ of them among IDUs (AIDS Epidemiological Bulletin, 2000).

In addition to HIV transmission, the common use of injection equipment and drug injecting paraphernalia were shown to be associated with other infectious diseases (Garfein et al., 1996; Oliveira et al., 1999). Among them, human T-cell leukemia virus (HTLV) has been documented in injecting drug user populations in America and Europe (Desgranges et al., 1996). Previous studies have also demonstrated the presence of this virus in certain populations in Brazil (Casseb et al., 1997; Britto et al., 1998; Carvalho et al., 1998; Ishak et al., 1998). A survey in blood donors of five state capitals showed an overall HTLV-I seroprevalence of $0.4 \%$ and none of the samples were confirmed positive for anti-HTLV-II (GalvãoCastro et al., 1997).

A 'sensitive/less sensitive' assay testing algorithm has been proposed as a serological strategy to identify recently infected individuals (Janssen et al., 1998) and was validated for estimating HIV incidence in blood donors and homosexual men (San Francisco Men's Health Study) in the USA. Moreover, this serological strategy was recently employed to identify HIV-1 incident infections in a Brazilian prison (Diaz et al., 1999).

In this paper, we present data from a cross-sectional study of injecting drug users in the city of Rio de Janeiro, to provide information on risk behavior, rates of HIV-1 and HTLV-I/II infection, as well as the distribution of HIV-1 different subtypes. Moreover, we used the dual testing strategy to estimate HIV-1 incidence in the studied group. 


\section{Material and methods}

\subsection{Study group and questionnaire}

A sample of 175 IDUs has been recruited in the streets and treatment centers for drug abuse, from 1994 to 1997, as part of an ongoing cooperative Multicenter Study on HIV/AIDS among IDUs. After signing an informed consent form, people were interviewed using a standard questionnaire based on the WHO Multicenter Study form (WHO International Collaborative Group, 1994a). The questionnaire addressed socio-demographic data, sexual and injecting risk behaviors, and information on the health status of interviewees. Clinical data were assessed by trained physicians, and the patients with HIV/AIDS were scored according to Centers for Disease Control and Prevention (CDC) clinical classification (Centers for Disease Control and Prevention, 1992).

\subsection{Whole blood and CD4+ count evaluation}

Five milliliters of ethylenediamine tetraacetic acid-anticoagulated blood and $10 \mathrm{ml}$ blood without anticoagulant were obtained from each patient. CD4 + T-cell determinations were carried out by flow cytometry using whole blood, and scored as $<200$ cells $/ \mathrm{mm}^{3}, \quad 200<\mathrm{CD} 4<400$ cells $/ \mathrm{mm}^{3}$ and $>400$ cells $/ \mathrm{mm}^{3}$. After centrifugation, the plasma was collected, aliquoted and stored at $-20^{\circ} \mathrm{C}$. The pellet $(2-3 \mathrm{ml})$ was suspended $(\mathrm{v} / \mathrm{v})$ in $0.5 \%$ Saponin $/ 0.4 \% \mathrm{NaCl}$, thoroughly vortexed, centrifuged $(400 \times g, 5 \mathrm{~min}$, room temperature), washed twice with phosphatebuffered saline by centrifugation in the same conditions, and stored for DNA extraction. Ten milliliters of blood without anticoagulant were also obtained and the sera were aliquoted, stored at $-20^{\circ} \mathrm{C}$ and used for serological tests.

\subsection{HIV and HTLV serostatus}

Serostatus for HIV-1 (Ortho HIV-1/HIV-2 AbCapture ELISA Test System; Ortho, NJ, USA; HIV-1 Uniform II; Organon, Boxtel, The Nether- lands) and HTLV-I/II (HTLV-I/II Cambridge Biotech, Worcester, USA) were determined by enzyme-linked immunosorbent assay (ELISA), and HIV-1 infection was confirmed by western blot assay (Cambridge Biotech Corp., Worcester, USA). Confirmation of HTLVI/II infection and differentiation between HTLV-I and -II were performed by western blot (HTLV Blot 2.4; Genelabs, Science Park Drive, Singapore).

\subsection{DNA preparation and polymerase chain reaction amplification of $H I V-1$ env sequences}

Genomic DNA was extracted using a phenol/ chlorophorm protocol and DNA samples $(\approx 1$ $\mu \mathrm{g})$ were polymerase chain reaction (PCR)-amplified by a nested protocol as previously described (Morgado et al., 1998a), using ED3/ED14 as the outer primer set and ED5/ED12, ES7/ES8 or ED31/ED33 as inner primer sets.

\subsection{Heteroduplex mobility assay}

HIV-1 subtyping was determined by heteroduplex mobility assay (HMA) as described elsewhere (Delwart et al., 1993). Briefly, $5 \mu 1$ ED31/ED33 or ED5/ED12 PCR-amplified products were mixed with $5 \mu 1 \mathrm{PCR}$-amplified plasmids $\left(94^{\circ} \mathrm{C}\right.$ for $3 \mathrm{~min}$, followed by incubation in ice for $10 \mathrm{~min}$ ) containing env fragments of the HIV-1 subtypes $\mathrm{A}-\mathrm{H}$ reference samples (Delwart et al., 1995), provided by the NIH AIDS Research and Reference Reagent Program. Each unknown sample was tested respectively against three reference plasmids of HIV-1 subtypes $\mathrm{B}$, and two of $\mathrm{C}, \mathrm{D}$ and F.

\subsection{Restriction fragment length polymorphism determination}

After the second round of PCR with ED31/ ED33 primers, 10 $\mu$ I HIV-1-amplified DNA were digested with $6 \mathrm{U}$ Fok $I$ restriction enzyme for $2 \mathrm{~h}$ at $37^{\circ} \mathrm{C}$, electrophoresed through $2 \%$ agarose gels, and the restriction fragments were evaluated under UV illumination, as previously described (Morgado et al., 1998a,b). 


\subsection{Dual testing strategy}

A sensitive 3A11 ELISA immunoassay (EIA) (Abbott Laboratories, Chicago, IL, USA) and a less sensitive version of the same EIA were used according to Janssen et al. (1998). HIV incidence for each studied group will be measured based on the following formula proposed by the authors: $I_{\text {ins }}=\left(n_{\text {ins }} / N\right) \times(365 / w) \times 100$, where $I_{\text {ins }}$ is the number of persons with $3 \mathrm{~A} 11$ reactive/3A11 insensitive reactive results, $N$ is the number of persons with HIV-negative results plus the number with $3 \mathrm{~A} 11$ reactive/3A11 insensitive test results, and $w$ is the estimated mean in days between seroconvertion on the 3A11 and 3A11 insensitive test.

\section{Results}

From the 175 IDUs participating in this study, $44(25.1 \%)$ were recruited in the streets and 131 $(74.9 \%)$ in drug treatment centers. The sample was composed mostly of males $(84.2 \%)$, and had a mean age of 33.3 years (S.D., 7.9). The vast majority was intravenous users of cocaine.

The serostatus for HIV-1 and HTLV-I/II was established for 171 samples. Four plasma samples were lost during laboratory manipulation, and the individuals were not available for further blood collection. Of the 171 samples analyzed, 46 $(26.9 \%)$ were positive for HIV-1. From this group, 15 patients $(32.6 \%)$ had CD4 + counts $<200 /$ $\mathrm{mm}^{3}, 11$ patients $(23.9 \%)$ had CD4 + counts between 200 and $400 / \mathrm{mm}^{3}$, and $19(41.3 \%)$ had CD $4+$ counts $>400 / \mathrm{mm}^{3}$. The CD $4+$ count was not available for one sample.

As shown in Table 1, most interviewees were males in their early thirties, with a low educational level. Unsafe injecting practices were common, and strongly and consistently (through different variables) associated with both infections (HIV and HTLV). Most of the interviewees have been engaged in different sexual partnerships, most of them unprotected (data not shown), although not a single variable related to sexual risk behaviors was found to significantly differ between those with and without HIV and/or HTLV infections, highlighting the core role of parenteral exposure in this population. Elsewhere (Oliveira et al., 1999; Telles et al., 1997), we explored in more detail the main risk factors for different infections (HIV and viral hepatitis) in this population through multivariate analyses.

\section{1. 'Less-sensitive' enzyme immunoassay}

Thirty-eight serum samples, two from HIV-1seronegative and 36 from HIV-1-seropositive individuals were tested using the dual testing strategy to detect early infected individuals (less than 129 days in average) in order to evaluate the seroincidence of HIV infection in the IDUs from Rio de Janeiro. The two seronegative samples (used as internal controls) were confirmed negative and one of the seropositive samples was also negative in the less sensitive assay. However, contrary to what was expected, this sample was obtained from an individual seropositive since 1996, already immunocompromised, with CD4 + counts $<200 /$ $\mathrm{mm}^{3}$. Therefore, no true incident case was found in the studied group.

\subsection{HTLV-I/II co-infection}

Positivity for anti-HTLV-I/II antibodies was detected in $29(17.0 \%)$ of the 171 plasma samples tested. Western blot assay was able to discriminate $22(75.9 \%)$ samples as HTLV-I, and seven (24.1\%) as HTLV-II infections. HIV-1/HTLV-I/II co-infections were verified among 15 (32.6\%) out of the $46 \mathrm{HIV}-1$-positive individuals. Indeed, ten (45.5\%) out of the 22 HTLV-I-positive individuals and five $(71.4 \%)$ out seven HTLV-II-positive ones were co-infected with HIV-1 (Table 2).

\subsection{HIV-1 env subtyping by HMA and RFLP with Fok I restriction enzyme}

From the 41 HIV-1-positive individuals analyzed by HMA, 31 (75.6\%) could be identified as infected by B subtype and ten $(24.4 \%)$ by subtype F. DNA samples from five patients did not yield PCR-amplified products to be typed. We assessed possible associations between HIV-1 subtypes and clinical and socio-demographical parameters; however, no association was found. 
Table 1

Main socio-demographic characteristics, parenteral and sexual risk behaviors among injection drug users, with and without HIV and/or HTLV infection, Rio de Janeiro, 1994-1996 a

\begin{tabular}{|c|c|c|c|c|c|c|}
\hline Variables & $\begin{array}{l}\text { Non-infected (i.e. } \\
\text { HIV-/HTLV-) }(n=111)\end{array}$ & $\begin{array}{l}\text { Infected by HIV } \\
\text { and/or HTLV }(n=60)\end{array}$ & $P$ value & $\begin{array}{l}\text { HIV-infected } \\
(n=46)\end{array}$ & $\begin{array}{l}\text { HTLV-infected } \\
(n=29)\end{array}$ & $\begin{array}{l}\text { HIV-/HTLV-infect } \\
\text { ed }(n=15)\end{array}$ \\
\hline Gender, male $(\%)^{\mathrm{b}}$ & $90 / 107(84.1 \%)$ & $50 / 59(84.7 \%)$ & 0.914 & $37 / 45(82.2 \%)$ & $23 / 28(82.1 \%)$ & $10 / 14(71.4 \%)$ \\
\hline Age (years) $(\text { mean })^{\mathrm{c}}$ & 32.82 & 33.37 & 0.680 & 32.22 & 36.9 & 36.73 \\
\hline Educational level ( $<8$ years) & $37 / 104(35.6 \%)$ & $28 / 58(48.3 \%)$ & 0.114 & $22 / 44(50.0 \%)$ & $14 / 28(50.0 \%)$ & $8 / 14(47,1 \%)$ \\
\hline $\begin{array}{l}\text { Injected at least once before } 18 \text { years } \\
\text { old }\end{array}$ & $42 / 101(41.6 \%)$ & $24 / 55(43.6 \%)$ & 0.804 & $19 / 43(44.2 \%)$ & $12 / 25(48.0 \%)$ & $7 / 13(53.8 \%)$ \\
\hline Needle sharing $(\%)$ (ever) & $62 / 102(60.8 \%)$ & $50 / 56(89.3 \%)$ & 0.000 & $38 / 43(88.4 \%)$ & $24 / 26(92.3 \%)$ & $12 / 13(92.3 \%)$ \\
\hline Needle sharing (last month) & $8 / 109(7.3 \%)$ & $9 / 51(17.6 \%)$ & 0.049 & $7 / 37(18.9 \%)$ & $4 / 26(15.5 \%)$ & $2 / 12(16.7 \%)$ \\
\hline $\begin{array}{l}\text { Shared with more than two different } \\
\text { persons in the last month }\end{array}$ & $3 / 103(2.9 \%)$ & $9 / 57(15.8 \%)$ & 0.009 & $6 / 43(14.0 \%)$ & $5 / 28(17.9 \%)$ & $2 / 14(14.3 \%)$ \\
\hline $\begin{array}{l}\text { Had more than two occasional } \\
\text { partners (past } 6 \text { months) }\end{array}$ & $4 / 103(38.8 \%)$ & $22 / 56(39.3 \%)$ & 0.956 & $17 / 93(39.5 \%)$ & $13 / 26(50.0 \%)$ & $8 / 13(61.5 \%)$ \\
\hline $\begin{array}{l}\text { Any male homosexual intercourse } \\
(\%)^{\mathrm{d}}\end{array}$ & $69 / 87(79.3 \%)$ & $34 / 48(70.8 \%)$ & 0.268 & $26 / 35(74.3 \%)$ & $15 / 22(68.2 \%)$ & $7 / 9(77.8 \%)$ \\
\hline $\begin{array}{l}\text { Shared injection equipment outside of } \\
\text { the town }\end{array}$ & $18 / 101(17.8 \%)$ & $21 / 56(37.5 \%)$ & 0.006 & $19 / 44(43.2 \%)$ & $6 / 26(23.1 \%)$ & $4 / 14(28.6 \%)$ \\
\hline
\end{tabular}

${ }^{\text {a }}$ Comparisons and $P$ values refer to interviewees neither infected by HIV nor by HTLV versus those infected by at least one of these viruses

b Chi-square or Fisher's exact test was used for categorical variables.

${ }^{\mathrm{c}}$ Student $t$ for means was used for discrete variables.

${ }^{\mathrm{d}}$ Refers to any homosexual intercourse in the past 5 years $(n=166 \mathrm{men})$. 
One important aspect to be assessed by studies in the field of HIV-1 molecular epidemiology in Brazil is the distinction between the classical North American/European subtype B samples, from the typical Brazilian HIV-1 subtype B samples presenting the antigenically distinct GWGR amino acid sequence in the crown of the V3 loop. The digestion of the $600 \mathrm{bp}$ ED31/ED33 PCRamplified DNA products, previously typed by HMA as B subtype, with Fok $I$ restriction enzyme, generates two patterns of two (400 bp-200 $\mathrm{bp})$ or three $(400 \mathrm{bp}-120 \mathrm{bp}-80 \mathrm{bp})$ restriction fragments. Using this approach, seven $(22.6 \%)$ out of the 31 subtype B samples from Rio de Janeiro City were digested with Fok $I$ and identified as corresponding to the typical GWGR subtype B samples found in Brazil, whereas the other B samples were not digested with this enzyme.

\section{Discussion}

The seroprevalence of $26.9 \%$ for HIV-1 antibodies in IDUs, verified in this study, was similar to the other studies conducted in Rio de Janeiro, which show, in general, moderate to high HIV seroprevalence rates among IDUs in Rio (14$33 \%$ ), and high levels of risk behavior (Telles et al., 1997; Bastos et al., 1999). No significant difference between the HIV seroprevalences in females and males was observed, unlike those detected in a recent survey in Salvador (BA),

Table 2

Summary of serologic data for HIV-1, HTLV-I and HTLV-II in a sample of IDUs in Rio de Janeiro, Brazil 1994-1996

\begin{tabular}{llll}
\hline & HIV-1 $(+)$ & HIV-1 $(-)$ & Total \\
\hline $\begin{array}{l}\text { HTLV-I }(+) \\
\text { HTLV-II } \\
(+)\end{array}$ & $10(45.5 \%)$ & $12(54.5 \%)$ & $22(13.0 \%)$ \\
$\begin{array}{l}\text { HTLV-I/II } \\
(+)^{\mathrm{a}}\end{array}$ & - & $02(28.6 \%)$ & $07(4.0 \%)$ \\
$\begin{array}{l}\text { HTLV-I/II } \\
(-)\end{array}$ & $29(21 \%)$ & $109(79 \%)$ & $138(80.7 \%)$ \\
$\begin{array}{l}\text { ND } \\
\text { Total }\end{array}$ & $02(66.7 \%)$ & $01(33.3 \%)$ & $03(1.7 \%)$ \\
\hline
\end{tabular}

\footnotetext{
a Without discrimination between HTLV-I and -II.
}

${ }^{\mathrm{b}}$ Not determined. where the seroprevalence of HIV infection in the female IDUs was $74.4 \%$, higher than observed in the male IDUs $(44.1 \%)$ studied in the same group (Dourado et al., 1999).

A higher prevalence, although non-statistically significant, of the $\mathrm{F}$ subtype was verified in the IDU group when compared with other exposure categories prevalent in Rio de Janeiro City, Brazil, as described in a previous report (Morgado et al., 1998a). Moreover, the subtype distribution showed to be associated only with gender, as three out four HIV-1-seropositive females evaluated in this study were infected with the $F$ subtype. However, a very low number of female injecting drug users could be enrolled for this study, probably reflecting a true restricted number of female IDUs in the Rio de Janeiro's drug scene (Telles et al., 1997; Bastos et al., 2000), a picture very different from the one observed in other Brazilian settings, for instance, with a much higher number of female IDUs in Santos, state of São Paulo (Carvalho et al., 1996).

The present study did not show any clear relationship between HIV-1 subtypes and IDUs when compared with other exposure categories in Rio de Janeiro, mainly sexually transmitted infections (heterosexual, homosexual and bisexual), as made evident by former publications of our research group (Morgado et al., 1998a), where similar frequencies of subtypes B and F have been observed. This finding differs from published data based on the patients attended in an AIDS clinic from city of São Paulo (Sabino et al., 1996), which was further confirmed based on an expanded survey (Rossini et al., 2001).

In this study, we also tried to estimate the incidence of HIV-1 infection in IDUs from Rio de Janeiro using the EIA double testing strategy. No specific effort was made to recruit new injectors (Friedman et al., 1998), making this a sample of quite old injectors as described elsewhere (Oliveira et al., 1999). Only one sample, corresponding to a subtype B infected individual, was found to be negative by the 'less sensitive' assay. However, this individual has been long-term infected at the time of blood collection and was already immunocompromised, confirming that caution has to be taken in the interpretation of this assay when the 
broad immunological profile is not available. Both subtype $\mathrm{B}$ and $\mathrm{F}$ individuals gave similar seropositive results in the 'sensitive' and 'less sensitive' assays used for this study. A possible complication in the use of the 'less sensitive/sensitive' dual testing strategy could be rendered by the higher anti-HIV-1 antibody reactivity observed by multivariate statistical analysis for those IDUs in comparison with sexually infected individuals (Bongertz et al. 1999).

High prevalence of HTLV-I/II infection and HIV-HTLV co-infection was observed in these samples. Although the frequency of HTLV-II was lower than the HTLV-I in our IDU study group, it was highly associated with HIV-1 co-infection. No previous data on HTLV-I/II infection among IDUs were available for Rio de Janeiro, so comparisons could only be made with data from Santos, São Paulo (Carvalho et al., 1998), and Salvador, Bahia (Dourado et al., 1999). Samples from IDUs, including those presented in the present study, and from former studies carried out in IDUs in Salvador (Dourado et al., 1999) and Santos (Carvalho et al., 1996), show a clear gradient in the seroprevalences for HTLV infection $(P=0.000)$, with the highest seroprevalence levels found for Salvador, intermediate levels for Santos, and the lowest for Rio de Janeiro.

The aforementioned national study showed exactly the same pattern for blood donors (GalvãoCastro et al., 1997), suggesting IDUs, due to their risky parenteral and sexual behaviors, are under particular risk for HTLV infection, but that, far from being a segregated population, they seem to exacerbate background infection patterns prevailing in the so-called general population, probably due to transmission of HTLV through unprotected sex between injecting drug users and their non-injecting sexual partners.

HIV/HTLV-I/II co-infection can pose problems in the field of clinical research and therapeutics, as was demonstrated by former studies (Schechter et al., 1997). The higher CD4 + lymphocyte counts observed in HIV/HTLV-I/II co-infection do not provide an immunological benefit, and may rather reflect HTLV-I-associated non-specific lymphocyte proliferation. However, we could not verify high levels of CD4 + counts in the co-in- fected individuals. Indeed, in the present study, 7/10 individuals co-infected with HTLV-I and 2/5 individuals co-infected with HTLV-II had CD4 counts below $200 / \mathrm{mm}^{3}$.

Activities directed towards the prevention of infectious diseases, especially in developing countries, where both resources and expertise are restricted, have basically addressed HIV/AIDS prevention. Viral hepatitis is also a matter of recent concern (Oliveira et al., 1999). HTLV-I/II infections have not merited attention thus far, although recently available data (Carvalho et al., 1996; Andrade et al., 1998) and the present data point to a disquieting picture among Brazilian IDUs.

In contrast with the high prevalence of HTLVII infections in North American and European IDUs, most infections among the Brazilian IDUs were caused by HTLV-I, which is of concern since HTLV-I is the etiologic agent of both tropical spastic paraparesis and T-cell leukaemia/ lymphoma. Comprehensive surveys with larger samples are urgently needed, to allow analyses of risk factors for HTLV-I/II infection in different settings.

Health care workers must be trained to systematically screen for HTLV-I/II for patients reporting risk behaviors and/or from endemic areas, a task that presents many difficulties in routine practice (Carvalho et al., 1998). Recent infections must be diagnosed promptly, in order to prevent further spread among injecting and sexual partners of IDUs and their offspring.

Preventive initiatives targeting the different blood-borne infections should be fully implemented in this population, including counseling, testing, provision of condoms and sterile injection equipment, enrollment of the infected individuals in follow-up studies, and the offer of the best practice available for the patients already ill.

\section{Acknowledgements}

The HIV-1 env Subtyping Kit was kindly provided by the NIH AIDS Research and Reference Reagent Program and UNAIDS. M.L.G., F.I.B. and P.T. are personally supported by grants from 
CNPq and FAPERJ. This project was supported by the National Coordination of STD and AIDS/ UNDCP/World Bank; World Health Organization-Global Programme on AIDS/United Nations Programme on AIDS (UNAIDS), the FIOCRUZ Integrated AIDS Program/Brazilian Ministry of Health, the Brazilian Research Council (CNPq), and Rio de Janeiro State Council (FAPERJ).

\section{References}

AIDS Epidemiological Bulletin [in Portuguese]. CN DST/ AIDS (December 1999-June 2000), Brazilian Ministry of Health, June 2000.

Andrade T, Dourado I, Galvão-Castro B. Associations among HTLV-1, HTLV-II and HIV in injecting drug users in Salvador, Brazil. J Acquir Immune Defic Syndr 1998;18:186-7.

Bastos FI, Strathdee SA, Derrico M, Pina F. Drug use and the spread of HIV/AIDS in South America and the Caribbean. Drug Educat Prevent Policy 1999;6:29-50.

Bastos FI, Lowndes CM, Derrico BS, Castello-Branco LR, Linhares-de-Carvalho MI, Oelemann W, Bernier F, Morgado MG, Yoshida CF, Rozental T, Alary M. Sexual behaviour and infection rates for HIV, blood-borne (BBI) and sexually transmitted infections (STI) among patients attending drug treatment centres in Rio de Janeiro, Brazil. Int J STD AIDS 2000;11:383-92.

Bongertz V, Guimarães ML, Soares-da-Costa MFG, Vellosodos-Santos, VG, The HEC/FIOCRUZ AIDS Clinical Research Group, Bastos FI, Telles PR, Morgado MG. Anti-HIV-1 seroreactivity in distinct transmission risk groups. J Clin Virol 1999;12:37-42.

Britto APCR, Galvão-Castro B, Straatmann A, Santos-Torres $\mathrm{S}$, Tavares-Neto J. HTLV-I/II infection in Bahia State, Brazil. Rev Soc Bras Med Trop 1998;31:35-41.

Carvalho HB, Mesquita F, Massad E, Bueno RC, Lopes GT, Ruiz MA, Burattini MN. HIV and infections of similar transmission patterns in a drug injectors community of Santos, Brazil. J Acquir Immune Defic Syndr 1996;12:8492.

Carvalho SMF, Oliveira MSP, Thuler LCS, Rios M, Coelho RCA, Rubim LC, Silva EM, Reis AN, Catovsky D. HTLV-I and HTLV-II infections in hematologic disorder patients, and healthy individuals from Rio de Janeiro, Brazil. J Acquir Immune Defic Syndr 1998;15:238-42.

Casseb J, Souza T, Pierre-Lima MT, Yeh E, Hendry RM, Gallo D. Testing problems in diagnosing HTLV infection among intravenous drug users with AIDS in São Paulo city, Brazil. AIDS Res Hum Retrovirus 1997;13:1639-41.

Center for Disease Control. Revised classification system for HIV infection and expanded surveillance case definition for AIDS among adolescents and adults. Morbid Mortal Weekly Rep 1992;4(RR-17):1-19.
Cornelissen M, Kampinga G, Zorgdrager F, Goudsmit $\mathbf{J}$ and UNAIDS Networks for HIV Isolation and Characterization. Human immunodeficiency virus type 1 subtypes defined by env show high frequency of recombinant gag genes. J Virol 1996;70:8209-12.

Couto-Fernandez JC, Janssens W, Heyndrickx L, Motte J, Fransen K, Peeters M, Delaporte E, Galvão-Castro B, Piot P, Van der Groen G. Study of the genetic and antigenic variability of HIV-1 strains isolated in Brazil. AIDS Res Hum Retrovirus 1994;10:1157-63.

Delwart E, Sphaer EG, Louwagie J, McCutchan FE, Grez M, Rubsamen-Waigmann H, Mullins JI. Genetic relationships determined by a DNA heteroduplex mobility assay. Science 1993;262:1257-61.

Delwart EL, Herring B, Learn Jr GH, Rodrigo AG and Mullins JI. Heteroduplex Mobility Analysis HIV-1 env Subtyping Kit, Protocol Version 3. NIH AIDS Research and Reference Program, 1995.

Desgranges C, Fillon S, Audoly G, Neisson-Vernant C, Bera O, Ouka M, Cesaire R, Buzelay L, Barin F. Presence of HIV-1 subtypes $B$ and F and HTLV-I in HIV/HTLV coinfected individuals of Martinique. J Acquir Immune Defic Syndr 1996;13:468-70.

Diaz RS, Kallas EG, Castelo A, Rawal BD, Busch MP. Use of a new 'less-sensitive enzyme immunoassay' testing strategy to identify recently infected persons in a Brazilian prison: estimate incidence and epidemiological tracing. AIDS 1999;13:1471-8.

Dourado I, Andrade T, Carpenter CL, Galvão-Castro B. Risk factors for human $\mathrm{T}$ cell lymphotropic virus type I among injecting drug users in Brazil: possibly greater efficiency of male to female transmission. Mem Inst Oswaldo Cruz 1999;94:13-8.

Friedman SR, Friedmann P, Telles PR, Bastos FI, Bueno R, Mesquita F, Des Jarlais DC. New injectors and HIV-1 risk. In: Stimson G, Des Jarlais DC, Ball A, editors. Drug Injecting and HIV Infection: Global Dimensions and Local Responses. Londres: UCL Press, 1998:76-90.

Galvão-Castro B, Loures L, Rodrigues LGM, Sereno A, Ferreira OC, Franco LGP, Muller M, Sampaio DA, Santana A, Passos LM, Proietti F. Distribution of human T-lymphotropic virus type 1 among blood donors: a nationwide Brazilian study. Transfusion 1997;37:242.

Gao F, Morrison SG, Robertson DL, Thornton CL, Craig S, Karlsson G, Sodroski J, Morgado MG, Galvão-Castro B, von Briesen H, Beddows S, Weber J, Sharp PM, Shaw GM, Hahn BH and WHO and NIAID Networks for HIV Isolation and Characterization. Molecular cloning and analysis of functional envelope genes from human immunodeficiency virus type 1 sequence subtypes A through G. J Virol 1996;70:1651-67.

Garfein RS, Vlahov D, Galai N, Doherty MC, Nelson KE. Viral infections in short-term injection drug users: the prevalence of the hepatitis $\mathrm{C}$, hepatitis $\mathrm{B}$, human immunodeficiency virus and human T-lymphotropic viruses. Am J Public Health 1996;86:655-61. 
Ishak R, Ishak MOG, Azevedo VN, Santos DEM, Vallinoto ACR, Saraiva JCP, Crescente JA, Hall WW. Detection of HTLV-IIa in blood donors in an urban area of the Amazon region of Brazil (Belém PA). Rev Soc Bras Med Trop 1998;31:193-7.

Janini LM, Pierniazek D, Peralta JM, Schechter M, Tanuri A, Vicente ACP, Torre ND, Pieniazek NJ, Luo CC, Kalish ML, Schochtman G, Rayfield M. Identification of single and dual infections with distinct subtypes of human immunodeficiency virus type 1 by using restriction fragment length polymorphism analysis. Virus Genes 1996;13:69-81.

Janssen RS, Satten GA, Stramer SL, Rawal BD, O'Brien TR, Weiblen BJ, Hecht FM, Jack N, Cleghorn FR, Kahn JO, Chesney MA, Busch MP. New testing strategy to detect early HIV-1 infection for use in incidence estimates and for clinical and prevention purposes. J Am Med Assoc 1998;280:42-8.

Lowagie J, Delwart EL, Mullins JI, Mc Cutchan FE, Eddy G, Burke DS. Genetic analysis of HIV-1 isolates from Brazil reveals the presence of two distinct genotypes. AIDS Res Hum Retrovirus 1994;10:561-7.

Morgado MG, Sabino E, Sphaer E, Bongertz V, Brígido L, Guimarães MD, Castilho EA, Galvão-Castro B, Mullins J, Hendry RM, Mayer A. Polymorphism in the V3 region of the envelope protein of HIV-1 in Brazil: divergence from prevalent North American/European subtype B strains and identification of newly described $\mathrm{F}$ subtype. AIDS Res Hum Retrovirus 1994;10:569-76.

Morgado MG, Guimarães ML, Gripp CBG, Costa CI, Neves I Jr, Veloso VG, Linhares-Carvalho MI, Castello-Branco LR, Bastos FI, Kuiken C, Castilho EA, Galvão-Castro B, Bongertz $\mathrm{V}$ and The Hospital Evandro Chagas AIDS Clinical Research Group. Molecular epidemiology of HIV1 in Brazil: high prevalence of B subtype and identification of an HIV-1 subtype D infection in Rio de Janeiro City. J Acquir Immune Defic Syndr 1998a;18:488-94.

Morgado MG, Guimarães ML, Neves I Jr, Veloso dos Santos VG, Linhares-de-Carvalho MI, Castello-Branco LR, Bastos FI, Castilho EA, Galvão-Castro B, Bongertz V and The Hospital Evandro Chagas AIDS Clinical Research Group. Molecular epidemiology of HIV-1 in Brazil: polymorphism of the antigenically distinct HIV-1 B subtype strains. Mem Inst Oswaldo Cruz 1998b;93:383-6.

Oliveira MLA, Bastos FI, Telles PR, Yoshida CFT, Schatzmayr HG, Pätzold U, Pauli G, Schreier E. Prevalence and risk factors for $\mathrm{HBV}, \mathrm{HCV}$ and $\mathrm{HDV}$ infections among injecting drug users from Rio de Janeiro, Brazil. Braz J Med Biol Res 1999;32:1107-14.

Potts K, Kalish M, Lott T, Orloff G, Luo C-C, Bernard M-A, Alves C, Badaró R, Suleiman J, Ferreira O, Schochetman G, Johnson W Jr, Ou C-Y, Ho J. Genetic heterogeneity of the V3 region of theHIV-1 envelope glycoprotein in Brazil. AIDS 1993; 7:1191-7.

Rossini MA, Diaz RS, Caseiro M, Turcato G, Accetturi CA, Sabino EC. HIV-1 subtypes among intravenous drug users from two neighbouring cities of São Paulo State, Brazil (2001) Braz. Of Med. Biol Res 2001; 34: 45-7

Sabino E, Shpaer E, Morgado MG, Diaz R, Bongertz V, Cavalcante S, Galvão-Castro B, Hendry M, Mullins J, Mayer A. Identification of an HIV-1 proviral genome recombinant between subtype $\mathrm{B}$ and $\mathrm{F}$ in PBMCs obtained from an. individual in Brazil. J Virol 1994;68:6340-6.

Sabino EC, Diaz R, Brigido LF, Learn GH, Mullins JI, Reingold AL, Duarte AJS, Mayer A, Busch MP. Distribution of HIV-1 subtypes seen in an AIDS clinic in São Paulo City, Brazil. AIDS 1996;10:1579-84.

Schechter M, Moulton LH, Harrison LH. HIV viral load and CD4 + lymphocyte counts in subjects coinfected with HTLV-I and HIV-1. J Acquir Immune Defic Syndr 1997; 15:308-11.

Telles PR, Bastos FI, Guydish J, Inciardi JA, Surratt HL, Pearl M, Hearst N. Risk behavior and HIV seroprevalence among injecting drug users in Rio de Janeiro, Brazil. AIDS 1997;11(suppl 1):S35-42.

WHO International Collaborative Group. Multi-City Study on Drug Injecting and Risk of HIV infection. Geneva: WHO, 1994a

WHO National Network for HIV Isolation and Characterization. HIV Type 1 variation in World Health Organizationsponsored vaccine evaluation sites: genetic screening, sequence analysis, and preliminary biological characterization of selected viral strains. AIDS Res Hum Retrovirus 1994b;10:1327-43. 